\title{
Hypoxia Controls Hypocotyl and Radicle Length in Germinated Impatiens Seeds
}

\author{
Nicole L. Waterland ${ }^{1,2}$ and Richard J. Gladon \\ Department of Horticulture, Iowa State University, Ames, IA 50011-1100
}

Additional index words. anoxia, germination, low oxygen, modified atmosphere, presowing treatment, Impatiens wallerana Hook. F.

\begin{abstract}
Sowing germinated seeds for bedding plant production can decrease the production time and reduce profit losses from sporadically or poorly germinating seeds. Low concentrations of $\mathrm{O}_{2}$ have been used to control radicle length in Impatiens wallerana Hook. F., but only a brief exposure period could be used (12 to $24 \mathrm{~h}$ ). The effects of prolonged exposures are unknown. Our first objective was to determine if impatiens seedlings could be acclimated to an extreme hypoxic environment by a preliminary exposure to a less severe hypoxic exposure. Our second objective was to determine the effects of longer-duration (greater than $24 \mathrm{~h}$ ) treatments at low- $\mathrm{O}_{2}$ concentrations on hypocotyl and radicle length, abnormal seedling development, and subsequent plant growth and development. Our third objective was to provide a commercial recommendation of a low-oxygen treatment or treatments that could be used for temporary storage of unused germinated seeds. Germinated seeds were placed in various combinations of $0.5 \%, 1.0 \%$, and $1.5 \% \mathrm{O}_{2}$ for either 4 days (Expt. 1) or 3 days (Expt. 2) followed by $24 \mathrm{~h}$ in air to simulate shipping. Germinated seeds were less tolerant of $0.5 \% \mathrm{O}_{2}$ than greater $\mathrm{O}_{2}$ concentrations, especially during the first 2 days of treatment, and more abnormal seedlings developed at $0.5 \% \mathrm{O}_{2}$. Germinated seeds were more tolerant of $0.5 \% \mathrm{O}_{2}$ during Days 3 and 4 of the treatment period or when days at $0.5 \% \mathrm{O}_{2}$ were interspersed between days of $1.0 \%$ or $1.5 \% \mathrm{O}_{2}$. This indicates that germinated impatiens seeds can tolerate extremely low- $\mathrm{O}_{2}$ for longer durations (greater than $24 \mathrm{~h}$ ) when first acclimated to lower $\mathrm{O}_{2}$ concentrations. Treatment of $1.5 \% \mathrm{O}_{2}$ for Days 1 and 2 followed by $0.5 \% \mathrm{O}_{2}$ for Day 3 is recommended for commercial use. Hypocotyl and radicle length was controlled to $1 \mathrm{~mm}$ without development of abnormal seedlings. Fully grown plants from seedlings that received low- $\mathrm{O}_{2}$ treatments were not different from control plants with regards to hypocotyl and radicle length, percentage abnormal seedlings, and plant growth and quality, ensuring there were no long-term detrimental effects.
\end{abstract}

Bedding plants account for $\approx 50 \%$ of the wholesale value of greenhouse crops in the United States (Miller, 2004; USDA, 2007). Virtually all bedding plants, including impatiens, are produced from plugs, and the use of plug trays has caused an increased demand on seed companies to produce high-quality seed lots to prevent empty cells in the plug trays (Cantliffe, 1998). To obtain 100\% stand establishment, some growers have resorted to sowing two to five seeds per cell (Pyle, 2000). Other growers sell a 512-plug tray as 475 seedlings, knowing that not all seedlings

Received for publication 8 July 2008. Accepted for publication 23 Oct. 2008.

A journal paper of the Iowa State University, College of Agriculture and Life Sciences, Ames, IA. This research was supported in part by a grant from the Seed Science Center, Iowa State University, Ames, IA, and State of Iowa funds.

We thank Philip M. Dixon of the Statistics Department, Iowa State University, for assistance with statistical analyses.

${ }^{1}$ Current address: The Ohio State University, Horticulture and Crop Science, 212 Williams Hall, Wooster, OH 44691.

${ }^{2}$ To whom reprint requests should be addressed; e-mail waterland.1@osu.edu. developed to constitute a full plug tray, or they "patch" empty cells with seedlings from other plug trays either mechanically or by hand. These costly and time-consuming losses associated with poor or sporadic germination might be avoided if a treatment were developed to control hypocotyl and radicle length so that previously germinated seeds could be sown mechanically and $100 \%$ stand establishment could be achieved.

Several techniques such as seed priming, or osmoconditioning, and presowing germination can improve stand establishment (Black and Bewley, 2000). Seed priming evolves exposing seeds to low external water potentials to initiation, but not completion, of germination. Thus, seed priming can be complex because seed imbibition must be stopped before the radicle emerges or the beneficial effects of priming are lost when the seed is dried (Job et al., 2000). When temperature, water potential, and duration of priming treatments are monitored, radicle emergence can be controlled. However, in a commercial greenhouse setting, this would be difficult because many different species and cultivars will have different requirements. In presowing germination, seeds are hydrated until the radicle protrudes, and certain species such as
Brassica oleracea var. capitata L. cv. Hawke can be dried and rehydrated to produce a normal growing plant (Finch-Savage and McKee, 1988). Other species such as Lycopersicum esculentum Mill. cv. Ailsa Craig are damaged by drying once the radicle has emerged (Berrie and Drennan, 1971).

Techniques such as density separation and fluid drilling allow removal of nonviable presown germinated seeds, and this permits quicker and more uniform germination (Pill, 1990; Taylor and Kenny, 1985; Taylor et al., 1981). Polking et al. (1994) researched the technique of presowing germination, but germinated seeds could be held for only 12 to $24 \mathrm{~h}$ at $1 \%$ to $2 \% \mathrm{O}_{2}$ without loss of seedling quality, and a longer holding time may be desirable. When seed priming or presowing treatments were successful, deterioration and improper seed storage lead to losses of longevity and seed efficacy (Bruggink et al., 1999; Taylor et al., 1998).

Low- $\mathrm{O}_{2}$ environments in the root zone reduce plant growth and development. In some scenarios, these effects of low- $\mathrm{O}_{2}$ are beneficial, including the control of radicle length (Polking et al., 1994). If the $\mathrm{O}_{2}$ concentration were too low, or if the exposure period were too long, seedlings could develop irreversible abnormalities. An appropriate $\mathrm{O}_{2}$ concentration in combination with a satisfactory exposure duration could allow germinated seeds to be held for several days, and those seeds could be sown subsequently with a resultant $100 \%$ stand establishment.

Hypoxia $\left(\mathrm{O}_{2}\right.$ levels $5 \%$ or less $)$ and anoxia $\left(\mathrm{O}_{2}\right.$ levels of $\left.0 \%\right)$ suppress seedling and plant growth and inhibit metabolism in several species. Root growth of salt marsh plants at $2.5 \%$ to $10 \% \mathrm{O}_{2}$ was reduced slightly, but under anoxia, growth ceased (Wijte and Gallagher, 1996). Reduced root growth under hypoxia also was noted in wheat (Triticum aestivum L.) (Biemelt et al., 1998) and barley (Hordeum vulgare L.) (Simojoki, 2000). For several species, a hypoxic pretreatment followed by an anoxic treatment increased survival during anoxia. Exposing oat (Avena sativa $\mathrm{L}$.) coleoptiles to $24 \mathrm{~h}$ hypoxia before $24 \mathrm{~h}$ of anoxia increased survival 4.5-fold when compared with nonpretreated seedlings (Kato-Noguchi, 2000). Arabidopsis (Arabidopsis thaliana L. Heynh) plants previously exposed to $5 \% \mathrm{O}_{2}$ were more tolerant of $0.1 \%$ $\mathrm{O}_{2}$ for $48 \mathrm{~h}$ in both roots and shoots than plants that received only an anoxic treatment, but hypoxic acclimatization did not improve tolerance to anoxia (Ellis et al., 1999). When two water submergence-tolerant and two water submergence-intolerant cultivars of rice (Oryza sativa L.) seedlings were exposed to $0 \% \mathrm{O}_{2}$ for $24 \mathrm{~h}$, without a hypoxic pretreatment, all died within 24 to $48 \mathrm{~h}$. After a hypoxic pretreatment, the two submergenceintolerant cultivars survived anoxia for $42 \mathrm{~h}$, and one of the submergence-tolerant cultivars survived for $72 \mathrm{~h}$ (Ellis and Setter, 1999). This same principle of pretreatment and acclimatization has been observed in stored pear fruit (Boersig et al., 1988). Thus, various organs of several species acclimatized 
to low- $\mathrm{O}_{2}$ when the $\mathrm{O}_{2}$ concentration has been reduced slowly, but plants and plant organs cannot tolerate a more rapid, direct drop to $0 \% \mathrm{O}_{2}$ or to extreme hypoxia.

Low concentrations of $\mathrm{O}_{2}$ ( $1 \%$ to $\left.2 \%\right)$ suppressed radicle length of impatiens, but the recommended exposure time (12 to $24 \mathrm{~h}$ ) was brief because longer exposures evoked more seedling abnormalities (Polking et al., 1994). A study of longer exposures to low- $\mathrm{O}_{2}$ concentrations that focuses on maintaining seedling health is needed. Our objectives were 1) to determine whether hypocotyl and radicle length of germinated impatiens could be controlled to $1 \mathrm{~mm}$ or less in response to greater than $24 \mathrm{~h}$ of extreme hypoxia if first acclimated to a less severe hypoxic exposure; 2) to assess whether abnormal seedlings (greater than 5\% abnormal seedlings) and plants of poorer quality developed when germinated seeds were held in low- $\mathrm{O}_{2}$ concentrations for more than 12 to $24 \mathrm{~h}$; and 3 ) to provide a recommendation of a low-oxygen treatment for temporary storage of germinated seeds.

\section{Materials and Methods}

Source and handling of plant material. One seed lot of 'Super Elfin White' impatiens seeds was obtained (PanAmerican Seed Co., West Chicago, IL) and stored in a desiccator at $4{ }^{\circ} \mathrm{C}$ with humidity of less than $30 \%$ (Hamrick, 2003). Seeds were imbibed for $60 \mathrm{~h}$ at $25 \pm 1{ }^{\circ} \mathrm{C}$ on two layers of Steel Blue Anchor ${ }^{\circledR}$ seed germination blotter (Anchor Paper, St. Paul, MN) saturated with $10 \mathrm{~mL}$ of deionized water in $100 \times 100 \times 15-\mathrm{mm}$ petri dishes sealed with Parafilm ${ }^{\circledR}$ (American National $\mathrm{Can}^{\mathrm{TM}}$, Chicago, IL). An imbibition period of $60 \mathrm{~h}$ was needed to achieve radicle and hypocotyl emergence from the testa as viewed through a $10 \times$ dissecting microscope. Seeds were germinated in a growth chamber under continuous irradiation with a photosynthetic photon flux $(P P F)$ of $127 \mu \mathrm{mol} \cdot \mathrm{m}^{-2} \cdot \mathrm{s}^{-1}$ from fluorescent and incandescent lamps.
Seeds were sown at one time, and 0.5 to $1.0 \mathrm{~mL}$ of deionized water was added $12 \mathrm{~h}$ after sowing. For the modified-atmosphere treatment, 25 germinated seeds were placed in a $5 \times 5$ array on two layers of a deionized, water-saturated $(8 \mathrm{~mL})$ germination blotter in a $9.0 \times 6.7 \times 1.2-\mathrm{mm}$ clear plastic box without a lid (Polking et al., 1994).

Hypoxia treatment. The clear plastic boxes with 25 germinated seeds were placed in a wide-mouth, 1-L Mason jar laid horizontally in a growth chamber. Jars were sealed with dome lids modified to contain a gas inlet, a gas outlet, and a sampling port (Polking et al., 1994). Modified atmospheres were obtained with a two-stage, capillary tube mixing system with two air exchanges per hour (Diesburg et al., 1989; Polking et al., 1994). Moisture in the germination blotter was maintained by adding 0.5 to $1.0 \mathrm{~mL}$ of deionized water every $12 \mathrm{~h}$ through the sampling port. To obtain a suitable hypoxic presowing germination treatment for a commercial setting, germinated seeds remained in the modified atmosphere (MA) for $4 \mathrm{~d}$ for Expt. 1 and 3 d for Expt. 2. Both experiments involved various combinations of $0.5 \%$, $1.0 \%$, and $1.5 \% \mathrm{O}_{2}$, balance $\mathrm{N}_{2}$ ( $\left.\mathrm{vol} / \mathrm{vol}\right)$, which was based on the results of preliminary experiments (Expts. 1 and 2, Tables 1 and 2, respectively). Oxygen concentration in the Mason jar was measured once daily during both experiments with a MiniOX ${ }^{\circledR}$ Responder Remote Oxygen Detector (Mine Safety Appliances Co., Pittsburgh, PA). Germinated seeds remained under continuous irradiation with a $P P F$ of $127 \mu \mathrm{mol} \cdot \mathrm{m}^{-2} \cdot \mathrm{s}^{-1}$ from fluorescent and incandescent lamps. Germinated seeds were held at $25 \pm 1{ }^{\circ} \mathrm{C}$ during the MA treatment. Seeds subsequently were exposed to ambient air $\left(20.9 \% \mathrm{O}_{2}\right)$ during a 24 -h dark simulated shipping period at $25 \pm 1{ }^{\circ} \mathrm{C}$ (Polking et al., 1994).

Hypocotyl and radicle length determination. After the 24-h simulated shipping period, hypocotyl and radicle length was measured on each germinated seed by using an Olympus ${ }^{\circledR}$ Model
SZH10 research stereo microscope (Olympus ${ }^{\circledR}$ America, Inc., Melville, NY). The microscope was equipped with AxioVision ${ }^{\circledR} 3.0$ software (Carl Zeiss ${ }^{\circledR}$, Inc., Thornwood, NY) that allowed digital measurement of the hypocotyl and radicle. Hypocotyl and radicles greater than $1 \mathrm{~mm}$ long were deemed too long because they may be damaged irreversibly during mechanical sowing. Abnormal seedling development was scored on the International Seed Testing Association (2003) definition of an abnormal seed. Abnormal seeds are defined as seedlings that are unable to develop normally.

Seedling recovery period. After hypocotyl and radicle length was determined in Expt. 1, the nine seedlings within the $5 \times 5$ array were placed in a plug tray for continued growth in a greenhouse. The remaining 16 seedlings (four groups of four) remained in the boxes and were replaced in the Mason jar and exposed to air for $7 \mathrm{~d}$ under continuous irradiation. In Expt. 2, the center column and center row remained in the clear plastic box, and the other 16 seedlings were placed in plug trays in the greenhouse. At the end of the 7-d recovery period, the seedlings held in the clear plastic boxes were harvested, and primary root length was determined.

Plug production. Seedlings used for plug production were planted in plug trays (512 cells/tray, $0.48 \mathrm{~cm}^{3} /$ cell) filled with Fafard ${ }^{\circledR}$ Germination Mix substrate (Conrad Fafard, Inc., Agawan, MA). Immediately after seedlings were planted, plug trays were placed under intermittent mist in a greenhouse under natural irradiance on 26 June, 24 July, and 8 Aug. 2004 for Expt. 1 and 4 Sept., 27 Sept., and 10 Oct. 2004 for Expt. 2. After 8 d, plug trays were transferred to another greenhouse with high-pressure sodium lamps (Model \# HPS400; Sunlight Supply ${ }^{\circledR}$, Inc., Vancouver, WA) that provided an average $P P F$ of 82 $\mu \mathrm{mol} \cdot \mathrm{m}^{-2} \cdot \mathrm{s}^{-1}$ of supplemental irradiance from 0600 to $2200 \mathrm{HR}$ each day in addition to natural irradiance. Greenhouse temperature varied from 22 to $32^{\circ} \mathrm{C}$. Seedlings were

Table 1. Effects of a 4-d, low-oxygen, modified-atmosphere treatment followed by $24 \mathrm{~h}$ in air in dark as a simulated shipping period (SSP) on germinated Impatiens wallerana Hook. F. 'Super Elfin White' seedling growth (Expt. 1).

\begin{tabular}{|c|c|c|c|c|c|c|c|c|c|}
\hline \multicolumn{4}{|c|}{ Oxygen concn $(\%)$} & $\begin{array}{l}\text { Hypocotyl and } \\
\text { radicle length after } \\
\operatorname{SSP}^{z}(\mathrm{~mm})\end{array}$ & $\begin{array}{l}\text { Primary root length } \\
\text { at end of } 7-\mathrm{d} \\
\text { recovery }(\mathrm{mm})\end{array}$ & $\begin{array}{l}\text { Abnormal seedlings } \\
\text { at end of } 7-d \\
\text { recovery }(\%)\end{array}$ & $\begin{array}{l}\text { Abnormal seedlings } \\
\text { after } 20 \mathrm{~d} \text { in } \\
\text { greenhouse }^{\mathrm{y}}(\%)\end{array}$ & \multicolumn{2}{|c|}{$\begin{array}{l}\text { Weights after } 20 \mathrm{~d} \text { in } \\
\text { greenhouse/seedling }\end{array}$} \\
\hline 1.5 & 1.0 & 1.0 & 0.5 & $0.79 \mathrm{bc}^{*}$ & $24.2 \mathrm{ab}$ & $8.3 \mathrm{~b}$ & $12.0 \mathrm{~b}$ & $195.9 \mathrm{NS}$ & $10.3 \mathrm{NS}$ \\
\hline 0.5 & 0.5 & 1.5 & 1.5 & $0.48 \mathrm{c}^{* * *}$ & $24.2 \mathrm{ab}$ & $31.0 \mathrm{a}^{\dagger \dagger \dagger}$ & $43.0 \mathrm{a}^{\dagger \dagger \dagger}$ & $189.0 \mathrm{NS}$ & $10.1 \mathrm{NS}$ \\
\hline 1.0 & 1.0 & 1.0 & 1.0 & $0.75 b c^{*}$ & $22.8 \mathrm{~b}^{\dagger \dagger}$ & $12.0 \mathrm{~b}$ & $9.3 \mathrm{~b}$ & $193.6 \mathrm{NS}$ & $10.6 \mathrm{NS}$ \\
\hline 1.5 & 0.5 & 1.5 & 0.5 & $1.10 \mathrm{ab}$ & $25.6 \mathrm{ab}$ & $4.3 \mathrm{~b}$ & $12.0 \mathrm{~b}$ & $192.5 \mathrm{NS}$ & $10.0 \mathrm{NS}$ \\
\hline
\end{tabular}

Values are means of three experimental units replicated over time. Statistical analysis using Proc GLM (generalized linear model) adjustment with Tukey's standardized range test was used to indicate if treatments were different from other treatments (as indicated by lower case letters), except the air control. Statistical analysis using Dunnett's one-tailed $t$ test was used to indicate treatments were different from the air control as indicated by the dagger(s).

${ }^{2}$ Hypocotyl and radicle lengths after the stimulated shipping period were compared statistically with a value of $1 \mathrm{~mm}\left(P\right.$ value indicated by $\left.{ }^{*}, * *, * * *\right)$ and with the other treatments (means separated by letters).

${ }^{y}$ Values are average of seedling cuttings harvested immediately below the cotyledonary node. Values were compared with those of other treatments and the air control $\left(P\right.$ value indicated by $\left.{ }^{\dagger}\right)$.

${ }^{*, * *, * * *}$ Significant at $P \leq 0.05,0.01$, or 0.001 , respectively. Numbers within a column not followed by one, two, or three asterisks are not different from $1 \mathrm{~mm}$. $\dagger, \dagger$, ${ }^{\dagger \dagger}$ Significant at $P \leq 0.05,0.01$, or 0.001 , respectively. Numbers within a column not followed by one, two, or three daggers are not different from the air control.

NS $=$ nonsignificant. 
Table 2. Effects of a 3-d, low-oxygen, modified-atmosphere treatment followed by $24 \mathrm{~h}$ in air in dark as a simulated shipping period (SSP) on germinated Impatiens wallerana Hook. F. 'Super Elfin White' seedling growth (Expt. 2).

\begin{tabular}{|c|c|c|c|c|c|c|c|c|}
\hline \multicolumn{3}{|c|}{ Oxygen concn $(\%)$} & $\begin{array}{l}\text { Hypocotyl and } \\
\text { radicle length after } \\
\operatorname{SSP}^{z}(\mathrm{~mm})\end{array}$ & $\begin{array}{c}\text { Primary root } \\
\text { length at end of } \\
\text { 7-d recovery }(\mathrm{mm})\end{array}$ & $\begin{array}{l}\text { Abnormal seedlings } \\
\text { at end of } \\
\text { 7-d recovery }(\%)\end{array}$ & $\begin{array}{l}\text { Abnormal seedlings } \\
\text { after } 20 \mathrm{~d} \text { in } \\
\text { greenhouse }^{\mathrm{y}}(\%)\end{array}$ & \multicolumn{2}{|c|}{$\begin{array}{l}\text { Weights after } 20 \mathrm{~d} \text { in } \\
\text { greenhouse/seedling }\end{array}$} \\
\hline 1.5 & 1.5 & 0.5 & $0.91 \mathrm{ab}$ & $22.5 \mathrm{NS}$ & $4.0 \mathrm{~b}$ & $8.3 \mathrm{~b}$ & $119.2 \mathrm{NS}$ & $7.4 \mathrm{NS}$ \\
\hline 1.5 & 0.5 & 0.5 & $0.61 b c^{* *}$ & $21.9 \mathrm{NS}$ & $22.0 \mathrm{~b}$ & $20.0 \mathrm{~b}$ & $98.3 \mathrm{NS}$ & $6.0 \mathrm{NS}$ \\
\hline 0.5 & 1.5 & 1.5 & 0.69 abc* & $23.6 \mathrm{NS}$ & $15.0 \mathrm{~b}$ & $10.0 \mathrm{~b}$ & $112.2 \mathrm{NS}$ & $6.9 \mathrm{NS}$ \\
\hline 1.0 & 1.0 & 1.0 & $0.85 \mathrm{ab}$ & $22.6 \mathrm{NS}$ & $7.7 \mathrm{~b}$ & $10.0 \mathrm{~b}$ & $104.8 \mathrm{NS}$ & $7.0 \mathrm{NS}$ \\
\hline 1.5 & 0.5 & 1.5 & $1.12 \mathrm{a}$ & $23.3 \mathrm{NS}$ & $4.7 \mathrm{~b}$ & $10.0 \mathrm{~b}$ & $114.7 \mathrm{NS}$ & $7.6 \mathrm{NS}$ \\
\hline
\end{tabular}

Values are means of three experimental units replicated over time. Statistical analysis using Proc GLM (generalized linear model) adjustment with Tukey's standardized range test was used to indicate if treatments were different from other treatments (as indicated by lower case letters), except the air control. Statistical analysis using Dunnett's one-tailed $t$ test was used to indicate treatments were different from the air control as indicated by the dagger(s).

${ }^{2}$ Hypocotyl and radicle lengths after the simulated shipping period were compared statistically with a value of $1 \mathrm{~mm}\left(P\right.$ value indicated by $\left.{ }^{*}, * *, * * *\right)$ and with the other treatments (means separated by letters).

${ }^{y}$ Values are average of seedling cuttings harvested immediately below the cotyledonary node. Values were compared with those of other treatments and with the air control $\left(P\right.$ value indicated by $\left.{ }^{\dagger}\right)$.

${ }^{*, * *, * * *}$ Significant at $P \leq 0.05,0.01$, or 0.001 , respectively. Numbers within a column not followed by one, two, or three asterisks are not different from 1 mm. $\dagger, \dagger$, ${ }^{\dagger}$ Significant at $P \leq 0.05,0.01$, or 0.001 , respectively. Numbers within a column not followed by one, two, or three daggers are not different from the air control.

NS $=$ nonsignificant.

watered daily with a fertilizer solution of $25 \%$ Excel $^{\circledR} \quad$ All-purpose $21 \mathrm{~N}-2.2 \mathrm{P}-16.6 \mathrm{~K}$ and $75 \%$ Excel $^{\circledR}$ CAL-MAG $15 \mathrm{~N}-2.2 \mathrm{P}-12.45 \mathrm{~K}$ fertilizers (Scotts-Sierra Horticulture Products, Marysville, $\mathrm{OH}$ ) at $100 \mathrm{mg} \cdot \mathrm{L}^{-1} \mathrm{~N}$ until $23 \mathrm{~d}$ after germination when the rate was increased to $150 \mathrm{mg} \cdot \mathrm{L}^{-1} \mathrm{~N}$. Seedlings remained in the plug trays until $28 \mathrm{~d}$ after germination. In Expt. 1, all seedlings were harvested for fresh and dry weights on Day 28 after germination. In Expt. 2, eight of the 16 seedlings were harvested on Day 28 after germination for fresh and dry weights, and the remaining eight seedlings were used for cell-pack production. Seedlings were harvested for fresh and dry weights by cutting the seedlings immediately below the cotyledonary node. Seedling fresh weight was measured, and seedlings were placed in a forced-air oven at $67^{\circ} \mathrm{C}$ for $72 \mathrm{~h}$ to obtain dry weight. Treatments with greater than $5 \%$ abnormal seedlings were deemed not suitable for commercial application.

Cell pack production. In Expt. 2, the eight seedlings not harvested for fresh and dry weights were transplanted into 1204 cell packs $\left(777.24 \mathrm{~cm}^{3} /\right.$ cell) filled with Sunshine LC-1 ${ }^{\odot}$ substrate (Sun-Gro Horticulture ${ }^{\circledR}$, Bellevue, WA). The cell packs were placed in a greenhouse with an average $P P F$ of 95 $\mu \mathrm{mol} \cdot \mathrm{m}^{-2} \cdot \mathrm{s}^{-1}$ of supplemental irradiance for the same time and temperature conditions as described in the plug production section. We continued to fertilize the seedlings with $150 \mathrm{mg} \cdot \mathrm{L}^{-1} \mathrm{~N}$. The number of days until appearance of the first visible flower bud (bud length of $\approx 2 \mathrm{~mm}$ ) and the first open flower (fully expanded corolla) were determined. On the day of the first fully open flower, the shoot tissue above the cotyledonary leaf scar of each plant was harvested for fresh and dry weight determinations.

Statistical analysis. Reported data are means of 25 seeds in each jar with four jars per replicate and three replications per treatment over time in the same growth chamber (randomized complete block design). Data obtained from seedlings in MAs were analyzed using Proc GLM (generalized linear model) with adjustments of a Tukey's standardized range test to determine differences from a standard hypocotyl and radicle length of $1 \mathrm{~mm}$ and differences between treatments, excluding the air control, and Dunnett's onetailed $t$ test to compare treatments with the air control. Data were analyzed by using SAS (SAS Institute, Inc., 2000).

\section{Results}

Preliminary experiments. Germinated impatiens seeds held in $2 \%$ or greater $\mathrm{O}_{2}$ for greater than $24 \mathrm{~h}$ produced hypocotyl and radicles lengths greater than $1 \mathrm{~mm}$ (data not presented), and germinated seeds held at $0 \%$ $\mathrm{O}_{2}$ for $24 \mathrm{~h}$ or longer routinely developed greater than 5\% abnormal seedlings (data not presented). Germinated seeds held at a constant concentration of $0 \%$ to $2.5 \% \mathrm{O}_{2}$ for 4 consecutive days produced seedlings that either had a hypocotyl and radicle length greater than $1 \mathrm{~mm}$ or greater than $5 \%$ abnormal seedlings (data not presented).

Hypocotyl and radicle/root length. Certain daily combinations of $0.5 \%, 1.0 \%$, and $1.5 \% \mathrm{O}_{2}$ for $4 \mathrm{~d}$ (Table 1) or $3 \mathrm{~d}$ (Table 2) controlled hypocotyl and radicle length to $1 \mathrm{~mm}$ or less after the 24-h simulated shipping period in air. Hypocotyl and radicle length of seedlings in all treatment combinations except $1.5 \%, 0.5 \%, 1.5 \%$, and $0.5 \%$ $\mathrm{O}_{2}$ for Days 1, 2, 3, and 4, respectively, followed by the simulated shipping period, were different from $1 \mathrm{~mm}(P=0.30)$ (Table 1). Hypocotyl and radicle length after the simulated shipping period for all treatment combinations except $1.5 \%, 1.5 \%$, and $0.5 \%$ $\mathrm{O}_{2}$ for Days 1, 2, and 3, respectively; $1.0 \% \mathrm{O}_{2}$ for all three days; $1.5 \%, 0.5 \%$, and $1.5 \% \mathrm{O}_{2}$ for Days 1, 2, and 3; and the air control were different from $1 \mathrm{~mm}(P=0.61,0.35,0.49$, and 0.25 , respectively) (Table 2 ). Seedlings in the air treatment had a hypocotyl and radicle length of $1.44 \mathrm{~mm}$ for Expt. 1 (Table 1) and $1.13 \mathrm{~mm}$ for Expt. 2 (Table 2), both of which were greater than our proposed 1-mm limit. Hypocotyl and radicle length of all treatments except $1.5 \%, 0.5 \%, 1.5 \%$, and $0.5 \% \mathrm{O}_{2}$ for Days $1,2,3$, and 4 , respectively, were different from the air control in (Table 1). In Expt. 2, only the treatments $0.5 \%$, $0.5 \%$, and $1.5 \% \mathrm{O}_{2}$ for Days 1,2 , and 3 , respectively, and $1.5 \%, 0.5 \%$, and $0.5 \% \mathrm{O}_{2}$ for Days 1, 2, and 3, respectively, were different from the air control (Table 2). All seedlings treated with any of the low concentrations of $\mathrm{O}_{2}$ lacked root hairs compared with seedlings held in air for the duration of the experiment. Primary root lengths were only different from air control in Expt. 1 with 4 consecutive days of $1.0 \% \mathrm{O}_{2}$ (Table 1 ).

Abnormal seedlings-Expt. 1. Germinated seeds held at $0.5 \% \mathrm{O}_{2}$ for Days 1 and 2 had $31 \%$ abnormal seedlings at the end of the 7 -d recovery period and $43 \%$ abnormal seedlings after 20 more days in the greenhouse, and these were different from all other treatments, except $0.5 \%, 1.0 \%, 1.0 \%$, and $1.5 \% \mathrm{O}_{2}$ for Days 1, 2, 3 and 4, respectively, and different from the air control (both $P<$ 0.0001 ) and greater than our proposed limit of $5 \%$ or less abnormal seedlings (Table 1). When germinated seeds received $0.5 \% \mathrm{O}_{2}$ during Days 3 and 4, we observed 10\% abnormal seedlings at the end of the 7-d recovery period and $9.3 \%$ at the end of 20 more days in the greenhouse, and these values were not different from those of the air control $(P=0.19$ and $P=0.40$, respectively), although they were greater than our proposed limit of $5 \%$ or less abnormal seedlings (Table 1). Treatments in which the $0.5 \%$ $\mathrm{O}_{2}$ exposure was on Days 2 and 4 with $1.5 \%$ $\mathrm{O}_{2}$ on Days 1 and 3 had $4.3 \%$ abnormal seedlings at the end of the $7-d$ recovery period and $12 \%$ after 20 more days in the greenhouse if the $0.5 \% \mathrm{O}_{2}$ exposure was on the second and fourth days (Table 1). 
Treatments in which the $0.5 \% \mathrm{O}_{2}$ occurred on Days 1 and 3 (with $1.5 \% \mathrm{O}_{2}$ on Days 2 and 4) had $12 \%$ abnormal seedlings at the end of the $7-\mathrm{d}$ recovery period and $8.3 \%$ after $20 \mathrm{~d}$ in the greenhouse (Table 1), and none of these was different from the air control $(P=0.68$, $P=0.24, P=0.10$, and $P=0.46$, respectively).

Abnormal seedlings-Expt. 2. Seed held at $0.5 \% \mathrm{O}_{2}$ for Days 1 and 2 (and $1.5 \% \mathrm{O}_{2}$ on Day 3) led to $56 \%$ abnormal seedlings at the end of the 7-d recovery period and 50\% abnormal seedlings after 20 more days in the greenhouse, and these were different from the air control (both $P<0.0001$ ) (Table 2). Germinated seeds that received $0.5 \% \mathrm{O}_{2}$ for Days 2 and 3 (with $1.5 \% \mathrm{O}_{2}$ on Day 3) developed $22 \%$ abnormal seedlings at the end of the $7-d$ recovery period and $20 \%$ after 20 more days in the greenhouse (Table 2), but these values were not different from those of the control $(P=0.13$ and $P=0.43$, respectively). The treatment in which the $2 \mathrm{~d}$ of $0.5 \% \mathrm{O}_{2}$ was separated by $1 \mathrm{~d}$ of $1.5 \% \mathrm{O}_{2}$ had $15 \%$ abnormal seedlings at the end of the 7 -d recovery period and $22 \%$ abnormal seedlings after 20 more days in the greenhouse (Table 2), and these values were not different from those of the control $(P=0.42$ and $P=$ 0.26 , respectively). The number of abnormal seedlings in the air control at both times of measurement was greater in Expt. 2 than in Expt. 1, most likely as a result of seed aging, but was not different $(P=0.25$ and $P=0.15$, respectively).

Fresh and dry weights. Neither fresh weight nor dry weight of the plants in any of the low- $\mathrm{O}_{2}$ treatments was different from the weight of plants in the air control (Tables 1 and 2). Fresh and dry weights of plants harvested after first full bloom were not different from air controls (data not presented).

First visible bud and first fully open flower. Number of days until appearance of the first visible bud (bud length of $\approx 2 \mathrm{~mm}$ ) and the first fully open flower were not different from the air control regardless of low- $\mathrm{O}_{2}$ treatment (data not presented).

\section{Discussion}

Use of low- $\mathrm{O}_{2}$ concentration to control hypocotyl and radicle length of impatiens required answers to two questions. First, will these low concentrations of $\mathrm{O}_{2}$ control hypocotyl and radicle length to $1 \mathrm{~mm}$ or less, and second, will abnormal seedlings and poorquality plants develop when germinated seeds are held in low $\mathrm{O}_{2}$ for more than $24 \mathrm{~h}$ ? From preliminary work, we determined that the usable limits were $0.5 \%$ to $1.5 \% \mathrm{O}_{2}$ for up to 4 d. From Expts. 1 and 2, we found certain daily combinations of $0.5 \%, 1.0 \%$, and $1.5 \%$ $\mathrm{O}_{2}$ for 4- or 3-d controlled hypocotyl and radicle length to $1 \mathrm{~mm}$ or less in seedlings measured after the simulated shipping period. Reduced respiration rate and less available adenosine-5' -triphosphate (ATP) (as a result of a low concentration of $\left.\mathrm{O}_{2}\right)$ is the most likely reason for this decreased growth. In lettuce (Lactuca sativa L.) seedlings, roots under anoxia rapidly lost ATP, but a hypoxic pretreatment $\left(5 \% \mathrm{O}_{2}\right.$ for $\left.1 \mathrm{~d}\right)$ slowed loss of ATP under anoxia (Kato-Noguchi, 2000). Without an adequate amount of ATP, additional cell growth would have been curtailed.

Timing of the application of the lowest $\mathrm{O}_{2}$ concentration is important. The sooner impatiens seedlings received the $0.5 \% \mathrm{O}_{2}$ concentrations, the shorter the hypocotyl and radicle length but the greater the percentage of abnormal seedlings. There are two possible reasons why more abnormal seedlings developed when the $\mathrm{O}_{2}$ concentration was low earlier rather than later. First, germinated seeds may be in a more developmentally critical stage of growth, and second, the rate of reduction in $\mathrm{O}_{2}$ concentration was too rapid during the initial exposure and did not allow the seeds to acclimatize to reduced $\mathrm{O}_{2}$, which might have activated the fermentation pathway. We are not aware of any research that supports the possibility that seedlings are in a more developmentally critical stage in the first day or two immediately after radicle protrusion as opposed to several days later. However, several researchers have addressed acclimatization to anoxic and more hypoxic conditions (Boersig et al., 1988; Ellis et al., 1999; Ellis and Setter, 1999; Kato-Noguchi, 2002).

In several species, a less hypoxic pretreatment was necessary for plants (Arabidopsis, oat, lettuce, and rice) and plant cells (pear fruit) to acclimatize to and to tolerate a subsequent anoxic or more hypoxic treatment (Boersig et al., 1988; Ellis et al., 1999; Ellis and Setter, 1999; Kato-Noguchi, 2002). When germinated impatiens 'Super Elfin White' seeds were exposed to $1.0 \%$ or $1.5 \%$ $\mathrm{O}_{2}$ before they were exposed to $0.5 \% \mathrm{O}_{2}$, fewer abnormal seedlings resulted than when the seedlings were exposed to $0.5 \% \mathrm{O}_{2}$ first. When germinated seeds were exposed to $0.5 \% \mathrm{O}_{2}$ immediately, i.e., without an acclimatization step at $1.0 \%$ or $1.5 \% \mathrm{O}_{2}$, more abnormal seedlings formed than when the treatments started with $1.0 \%$ or $1.5 \% \mathrm{O}_{2}$ (Tables 1 and 2). When germinated impatiens seeds are exposed immediately to $0.5 \% \mathrm{O}_{2}$, anaerobic respiration may be initiated, which damages the seedlings through the accumulation of either lactate or ethanol, and subsequent increases in the $\mathrm{O}_{2}$ concentration reduce the percentage of abnormal seedlings, but they do not eliminate them (Tables 1 and 2).

Our recommendations for treating germinated impatiens seeds must be based on three factors: 1) hypocotyl and radicle length at the end of the simulated shipping period; 2) the percentage of abnormal seedlings after an additional $20 \mathrm{~d}$ in the greenhouse; and 3) the quality of plants produced from those seedlings. If the plants at the end of the production cycle in the greenhouse are delayed or do not develop correctly, then the practical application of this type of treatment is diminished. Based on our results, we cannot recommend a 4-d, low- $\mathrm{O}_{2}$ treatment for germinated impatiens seeds because abnormal seedling development was greater than $5 \%$ for all but one of the seven sets of conditions we tested (Table 1). We recommend treatment of $1.5 \% \mathrm{O}_{2}$ for
$2 \mathrm{~d}$ followed by $0.5 \% \mathrm{O}_{2}$ for $1 \mathrm{~d}$. This treatment provided acceptable control of hypocotyl and radicle length ( $1 \mathrm{~mm}$ or less) without the development of greater than $5 \%$ abnormal seedlings; and treated seeds, when fully grown and flowering, were not different from control plants in any of the parameters measured.

Initial seed quality was high and seeds lots of high quality would have a slightly enhanced ability to tolerant periods of low oxygen. The use, however, of low- $\mathrm{O}_{2}$ treatments on poor- or lower-quality seed lots would allow for easy selection of viable seeds regardless of difference in initial seed lot quality. Poor-performing seeds would be easily removed allowing for the highest quality and most stress-tolerant seeds to be selected. These seedlings would perform better in postproduction setting where they would encounter additional stresses.

We included a 24-h simulated shipping period in our experiments so that we could simulate overnight shipping of treated seeds from a seed company to a smaller grower. However, large growers who use $\mathrm{O}_{2}$ treatments at their greenhouse would not need this 24-h shipping period. If a large grower sowed treated seeds without the 24-h simulated shipping period, there would be less hypocotyl and radicle length, and less possible damage, than we observed. Large growers then could save any unsown seeds, place them in an appropriate low- $\mathrm{O}_{2}$ environment for 1 or $2 \mathrm{~d}$, and subsequent germinated seeds could be sown over several days. This low- $\mathrm{O}_{2}$ treatment can be a method for controlling hypocotyl and radicle length of germinated seeds without the development of abnormal seedlings that cause losses in stand establishment. Ultimately, if growers removed nonviable seed before the low- $\mathrm{O}_{2}$ treatment, they could obtain $100 \%$ stand establishment by sowing germinated seeds, which would increase efficiency in greenhouse production of impatiens.

\section{Literature Cited}

Berrie, A.M.M. and D.S.H. Drennan. 1971. The effect of hydration-dehydration on seed germination. New Phytol. 70:135-142.

Biemelt, S., U. Keetman, and G. Albrecht. 1998. Re-aeration following hypoxia or anoxia leads to activation of the antioxidative defense system in roots of wheat seedlings. Plant Physiol. 116:651-658

Black, M. and J.D. Bewley. 2000. Seed technology and its biological basis. Sheffield Academic Press, Sheffield, UK.

Boersig, M.R., A.A. Kader, and R. Romani. 1988. Aerobic-anaerobic respiratory transition in pear fruit and cultured pear fruit cells. J. Amer. Soc. Hort. Sci. 113:869-873.

Bruggink, G.T., J.J.J. Ooms, and P. van der Toorn. 1999. Induction of longevity in primed seeds. Seed Sci. Res. 9:49-53.

Cantliffe, D.J. 1998. Seed germination for transplants. HortTechnology 8:499-503.

Diesburg, K.L., N.E. Christians, and R.J. Gladon. 1989. A continuous air-exchange roomette and gas-meting system. Crop Sci. 29:344-348.

Ellis, M.H., E.S. Dennis, and W.J. Peacock. 1999. Arabidopsis roots and shoots have different 
mechanisms for hypoxic stress tolerance. Plant Physiol. 119:57-64.

Ellis, M.H. and T.L. Setter. 1999. Hypoxia induces anoxia tolerance in completely submerged rice seedlings. J. Plant Physiol. 154: 219-230.

Finch-Savage, W.E. and M.T. McKee. 1988. A study of the optimum drying conditions for cabbage seed following selection on the basis of a newly-emerged radicle. Ann. Appl. Biol. 113:415-424.

Hamrick, D. (ed.). 2003. Ball redbook. 17th Ed. Vol. 2: Crop production. Ball Publishing Co., Batavia, IL.

International Seed Testing Association. 2003. International rules for seed testing. 3rd Ed. The International Seed Testing Association, Bassersdorf, Switzerland.

Job, D., I. Capron, C. Job, F. Dacher, F. Corbineau, and D. Côme. 2000. Identification of germination-specific protein markers and their use in seed priming technology, p. 449-459. In: Black, M., K.J. Bradford, and J. VázquezRamos (eds.). Seed biology: Advances and applications. University Press, Cambridge, MA.

Kato-Noguchi, H. 2000. Abscisic acid and hypoxic induction of anoxia tolerance in roots of lettuce seedlings. J. Expt. Bot. 51:1939-1944.

Kato-Noguchi, H. 2002. Hypoxic induction of anoxia tolerance in Avena coleoptiles. J. Plant Physiol. 159:751-755.

Miller, M.N. 2004. An industry in transition. GrowerTalks 68:70-82.

Pill, W.G. 1990. Seedling emergence and yield from hydrated collard seeds fluid-drilled in high-phosphorus gel. HortScience 25:15891592.

Polking, G.F., R.J. Gladon, and D.S. Koranski. 1994. Temporary suppression of radicle elongation of germinated impatiens seeds by low oxygen concentrations. HortScience 29:10311033.

Pyle, A. 2000. Germination of perennial seed. Can. Greenhouse Conf. 4 June 2003. <http://www canadiangreenhouseconference.com/index.cgi? filename $=$ Talks $\% 20-\% 20$ Pyle1\&dir=Talks $/$ Talks$2000>$.
SAS Institute, Inc. 2000. SAS/STAT TM User's Guide. Version 8. SAS Institute, Inc., Cary, NC.

Simojoki, A. 2000. Responses of soil respiration and barley growth to modified supply of oxygen in the soil. Agr. Food Sci. Finland 9:303-318.

Taylor, A.G., P.S. Allen, M.A. Bennett, K.J. Bradford, J.S. Burris, and M.K. Misra. 1998. Seed enhancements. Seed Sci. Res. 8:245256.

Taylor, A.G. and T.J. Kenny. 1985. Improvement of germination seed quality by density separation. J. Amer. Soc. Hort. Sci. 110:347-349.

Taylor, A.G., S.W. Searcy, J.E. Motes, and L.O. Roth. 1981. Separation, singulation, and precision planting of germinated seed. HortScience 16:198-200.

USDA. 2007. Floriculture crops 2006 summary. Agricultural Statistics Board, NASS, USDA.

Wijte, A.H.B.M. and J.L. Gallagher. 1996. Effect of oxygen availability and salinity on early life history stages of salt marsh plants. II. Early seedling development advantage of Spartina alterniflora over Phragmites australis (Poaceae). Amer. J. Bot. 83:1343-1350. 